\title{
Network Policy E-Samsat in Local Revenue Office of West Java Province
}

\section{${ }^{* 1}$ Yulia Hanoselina, ${ }^{2}$ Iip Permana, ${ }^{3}$ Krismena Tovalini, ${ }^{4}$ Yoserizal, ${ }^{5}$ Rahmadhona Fitri Helmi}

\author{
1,2,5 Universitas Negeri Padang, Indonesia; yuliahanoselina@fis.unp.ac.id \\ ${ }^{3}$ STIA Adabiah Padang, Indonesia; tovalinikrismena@gmail.com \\ ${ }^{4}$ Universitas Andalas, Indonesia; jarjisyoserizal@gmail.com
}

Received: July 7, 2021; In Revised: October 19, 2021; Accepted: November 23, 2021

\begin{abstract}
The local revenue office as a government agency takes steps to implement e-government in terms of service delivery of motorized vehicle taxes and ratification of STNK in order to improve the quality of public services to the community. This study aims to find out and analyze the E-Samsat Implementation Policy Network in more detail at the West Java Bapenda. The research method and approach are carried out by qualitative research methods with a descriptive approach. Data collection techniques through observation methods, semi-structured interviews and documentation. Procedures to test the validity of the data, among others, through triangulation of data with sources, processes and time. The theory used is the Theory of Policy Network Dimensions by Frans Van Waarden (1992). The research results are that the E-Samsat Implementation Policy Network already has and carries out the main tasks and functions of each as stated in the rules of the Cooperation Agreement. The structure and pattern of power relations in the implementation of e-samsat are the same/equal between fellow e-samsat coaching teams. The E-Samsat Advisory Team is the formulator and implementer of the policy, while Bank BJB is a channel for receiving payments (payment points) for e-samsat and as a liaison or collaborating with other parties or third parties such as other banks, Indomaret, Alfamart, Tokopedia and Bukalapak. And if there are problems related to e-samsat, they are together to solve these problems according to their respective roles and produce a joint decision.
\end{abstract}

Keywords: Public Policy, Policy Network, E-government, Local Revenue Office, E-Samsat

\section{Introduction}

E-government has become a necessity in response to changes in the strategic environment that demands efficient, effective, public-oriented, transparent and accountable state administration (Habibullah, 2010). The step towards e-government has been introduced since 2001 through the Presidential Instruction of the Republic of Indonesia Number 6 of 2001 concerning the Development and Utilization of Telematics in Indonesia which states that government officials must develop and use telematics technology to support good governance and accelerate the democratic process. Then the issuance of the Presidential Instruction of the Republic of Indonesia Number 3 of 2003 concerning National Policies and Strategies for the Development of E-government is a step by the Indonesian Government to utilize ICT in the government process and create an information-based Indonesian society. In addition, the 
application of electronic-based services has also minimized the corrupt behaviour of these public servants. Based on this, Bapenda has taken steps to implement e-government in matters of motor vehicle tax payment services and ratify STNK to improve the quality of public services to the community. One of the West Java Bapenda's policies with the concept of e-government to overcome problems in conventional SAMSAT services and provide alternatives and innovations in paying motor vehicle taxes and ratifying STNK is E-Samsat.

E-Samsat was launched on November 22, 2014. This service includes the payment of motor vehicle tax and vehicle registration ratification. In collaboration with PT, the West Java Provincial Samsat Development Team consists of West Java Province (Bapenda Jabar), West Java Regional Police (Directorate of Traffic), and Jasa Raharja. Regional Development Bank of West Java and Banten, Tbk. (Bank BJB), Bank Central Asia (BCA) and Bank Negara Indonesia (BNI) launched breakthrough innovations in E-Samsat services through the banking system by utilizing information technology facilities and electronic transactions.

E-Samsat Jabar provides many advantages and conveniences, and taxpayers make payments via ATM. It is also expected to avoid brokers, eliminate tax revenue corruption, accurate tax calculations to be paid, and of course, provide convenience for taxpayers (https:/ /bapenda.jabarprov.go.id/, 2021). With this service, the annual tax payment for motorized vehicles with West Java plates is enough to be done through ATMs of Bank BJB, Bank BCA and Bank BNI, as well as parties who have become joint partners. E-Samsat is a breakthrough in accordance with the government's program to launch an electronic payment scheme. With the implementation of the E-Samsat service, it is hoped to help the government increase Regional Original Revenue (PAD).

From previous research, it was found that there are still problems that occur in the implementation of E-Samsat including many still experiencing problems such as the lack of expansion of cooperation with banks and the limitations of other ATMs so that public access is lacking, there are still many people who do not have bank accounts (Bahtiar, 2018). ), internet network access for payment codes is still limited, there are still obstacles in matching NIK (ID Number) at the bank and the validity of vehicle ownership, the lack of socialization makes people not optimally use E-Samsat (Hertiarani, 2016), the service is still not fast if there is a network troubleshooting problem during the service process. The service is still not right on the installation of the SAMBARA application, Android gadget users can only use it, and there are brokers and at the time of validating the STNK (Silvia, 2019). There are still many problems related to the role of the involvement of the actors involved in the implementation of the ESamsat policy. Researchers are interested in studying in terms of the policy network for the implementation of E-Samsat in the West Java Bapenda. Based on the problems above, the researchers will focus on "Network Policy for the Implementation of E-Samsat at Bapenda Jabar".

\section{Methods}

The research method used is a qualitative approach with a descriptive research design. The use of this research method is because the researcher is trying to explain the E-Samsat Implementation Policy Network at Bapenda Jabar, a qualitative approach is more suitable to be used to analyze information and data obtained from informants related to this research problem (Pasolong, 2012) while the type of descriptive research in this research This is used to describe, describe and systematically explain (Nazir, 2003) the E-Samsat Implementation Policy Network at the West Java Bapenda. This research focuses on the E-Samsat 
Implementation Policy Network at the West Java Bapenda. The focus of this research will be based on the theory used is the Theory of Policy Network Dimensions by Frans Van Waarden (1992). The indicators include Actor, Function, Structure, Institutionalization, Rules of conduct, Power relations and Actor strategies. The location of the research was carried out at the West Java Bapenda.

Researchers' sources of research data are in the form of primary data and secondary data (Pasolong, 2012). The data collection technique used by the researcher was purposive sampling, namely (Pasolong, 2012): 1) semi-structured interview (in-depth interview) (Hadi, 2004) with the Head of the West Java Bapenda Office, Head of Revenue I, Information Management and Documentation Officer (PPID) and E-Samsat User Community, 2) field observations (Satori \& Aan, 2012) at Bapenda Jabar and 3) documentation (Moleong LJ, 1996) using prepared tools such as mobile phone cameras, notebooks, and recording devices. The technique of testing the validity of the data is a triangulation of sources, strategies and time (Sugiyono, 2009). Data analysis techniques used by researchers: 1). The available data are classified and reduced first by grouping and discarding unnecessary data, 2). Then, the data that has been grouped has just been presented and lastly analyzed, 3). Finally, the information is verified, and conclusions are drawn (Huberman, 1992).

\section{Results and Discussion}

Bapenda Jabar is a public organization that is always continuing to improve quality and beneficial services for the community and benefit the image of the government apparatus itself. Bapenda Jabar constantly improves and builds its networks with other stakeholders who can help and work together to produce a policy that can solve problems in its services, especially in E-Samsat services.

Waarden (1992) suggests that the policy network is a relationship formed due to a coalition between government actors, the public, and the private sector. (Kickert et al., 1997) suggests that the policy network examines the pattern of social relations between several actors dependent on each other where they play a role in the public policy process. Enroth (2011) suggests that policy networks have one characteristic, namely the existence of interdependence, coordination, and pluralism. Benson (1982) presents a grid of policies in terms of complex organizations linked to each other through resource dependence. (Kenis \& Schneider, 1991) suggest that policy networks are described in several categories. They are first described as actors, Second, linkages between actors, third, boundary.

Rhodes (1995) suggests that the interaction between several government departments and organizations with community organizations is a policy network in the public policy process. (Howlett and Ramesh, 1995) suggest that policy networks will be accommodated in organizations. These organizations are often called policy subsystems. Howlett Nan Ramesh mentions the policy subsystem as being built from sub-governments, namely groups in society and government actors who regularly interact in a fixed pattern. (Carlsson, 2000) suggests network policy as a network approach. Policy networks are described as actors, their relationship, and their boundaries. Actors are involved in a policy, both from public and private organizations. Relationships between actors are served through communication, information, trust and other policy sources. The boundary of a policy network is not a formal institution but a process of mutually beneficial relationships of relevant functions and structures. 
By creating a policy network for implementing E-Samsat that involves several parties, namely the E-Samsat Development Team consisting of the West Java Bapenda, West Java Police Chief (Dirlantas Jabar), Jasa Raharja and in collaboration with PT. BJB, Tbk. as well as involving other parties such as BNI Bank, BCA Bank, Telkom, Alfamart, Indomaret, Bukalapak and Tokopedia.

The E-Samsat Implementation Policy Network already has its respective roles and has carried out its respective primary duties and functions as stated in the rules of the Cooperation Agreement. However, the West Java Bapenda also always builds its networks to formulate and implement its policies. This will be important in solving the problems that occur in the implementation of the E-Samsat so that it can achieve and implement the goal of the E-Samsat application made.

\section{Actors}

In policy formulation, actors are related to the number of people involved (participants). This factor determines the size of the network to be built. Furthermore, the characteristics of the policy network will be influenced by the types of actors from different backgrounds. Actors in this policy network are individuals but can also be in organizations as the actors involved can also represent certain groups/parties. In carrying out the work activities of an organization, human resources are needed to realize these work activities, meaning that human resources are the main component in the running of organizational activity. (Hanoselina, Wahyuni, Tovalini, \& Yoserizal, 2020). In this case, the actors involved in implementing E-Samsat are the West Java Bapenda, West Java Regional Police (Dirlantas), Jasa Raharja and in collaboration with PT. Bank BJB, Tbk.

Figure 1

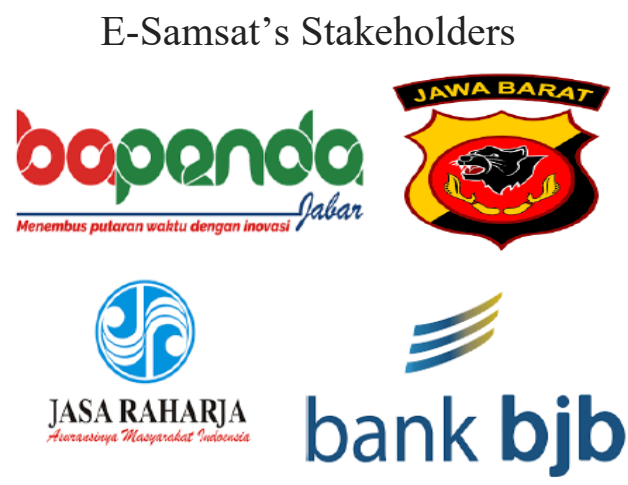

Source: Processed by Researcher, 2021

Bapenda Jabar has the main tasks in carrying out the following functions: 1). To support government affairs in the financial sector, aspects of regional income, including planning and development, the revenue I, revenue II and guidance and control, which are the province's authority, 2). Carry out deconcentration tasks and carry out assistance tasks according to their field of duty based on the provisions of the law. While its functions are as follows: 1). Implementation of the formulation of technical policies in the financial sector of the regional income aspect, which is the authority of the Provincial Region. 2). The implementation of financial management aspects of regional revenue management is the Provincial Region's authority. 3). Implementation of the Facilitation of the Implementation of Regional Revenue and Public Service Duties. 4). Administration of the Agency. 5). Implementation of evaluation and reporting of the Agency. 6). Performance of other functions in accordance with the primary duties and functions. 
The West Java Regional Police has the main task of carrying out the main functions of the Police in maintaining security and public order, law enforcement and providing protection, protection and service to the community as well as other main tasks of the Police in their jurisdiction, in accordance with applicable laws and regulations. Within the police organization. While its functions are as follows, First, to provide police services to citizens in need, in the form of receiving and handling reports or complaints and requests for assistance or assistance, service complaints on the actions of members of the National Police and service letters - permits or statements in accordance with the provisions of law and regulations or policies that apply within the Police organization. Second, as Intelligence in the field of security, including joints, both as part of the activities of the upper units and as input for the preparation of the Regional Police's operational activity plan in the context of preventing disturbances and maintaining domestic security. Third, carry out investigations and investigations of criminal acts, including identification functions and field forensic laboratory functions, in the context of law enforcement.

Fourth, carry out police compliance, which includes patrol activities, which include setting, guarding and overseeing community and government activities, including prosecution of minor crimes, and securing particular objects which have VIPs, tourism and other $\mathrm{vital} / \mathrm{specific} \mathrm{objects,} \mathrm{in} \mathrm{the} \mathrm{context} \mathrm{of} \mathrm{preventing} \mathrm{crime} \mathrm{and} \mathrm{maintenance} \mathrm{of} \mathrm{public} \mathrm{order.} \mathrm{Fifth,}$ carry out police traffic, which includes regulating activities, guarding and patrolling traffic, and registration and identification of motorized vehicles, in the context of law enforcement and fostering security, order and smooth traffic. Sixth, the waters police, which includes the implementation of patrol activities including the first handling of criminal acts and the search and rescue of accidents in the waters and the development of coastal or marine communities, in the context of preventing crime and maintaining the security of the waters. Seventh, conducting community guidance, which includes community counselling and fostering or developing forms of self-defence to increase awareness and obedience of citizens to the law and the PerUU, growth and development of community participation in carrying out security and charge product, the establishment of Polri-community relations. Conducive to the implementation of the main tasks of the Police. Eighth, other functions, based on the provisions of the PerUU and or its implementing regulations, include temporarily serving the interests of the community before being handled by the authorized agency or party.

Jasa Raharja has the following main tasks: 1). They are collecting and managing funds from the public in the form of mandatory passenger accident liability funds (compulsory contributions) and road traffic accident funds (mandatory donations). 2). Provide compensation funds to people who experience road traffic accidents and passengers on public transportation. While, PT. Bank BJB, Tbk has the following main tasks: 1). Contribute and participate as a regional economic driver. 2). Become the leading partner of the local government in financial management. 3). Provide the best service to customers. 4). Provide the best and sustainable benefits to the relevant stakeholders. 5). Improving the process of financial inclusion for the community through banking digitization.

\section{Function}

The network is a communication medium that manifests in several functions. Its functions depend on the needs, intentions, resources, and strategies of the actors involved in the activity. The concept of this function then forms a perspective link between structures and actors in the policy network. The primary function of the policy network is as a tool used to 
increase the intensity of the relationship between parties with interest in a public policy, both at the formulation and implementation stages.

The functions or roles of each actor in the implementation of E-Samsat: Bapenda Jabar has the following functions: 1). As the initiator of e-samsat. 2). As the main implementer of esamsat. 3). As the main media related to solving e-samsat problems. 4). As the owner of the central database related to e-samsat. 5). As a tax collector / e-samsat. The West Java Regional Police (Dirlantas) functions 1). As verification of problematic or non-problem vehicles. 2). As a coordinator in the implementation of e-samsat. 3). As verification and registration of motorized vehicles.

Jasa Raharja has the following functions: 1). As an insurance income party 2). As a mandatory donation of funds. PT. Bank BJB, Tbk. has the following functions: 1). As a channel for receiving payments (payment points), e-samsat. 2). As a payment aggregator, he is referred to as a third party who collects all merchant transactions through one account. 3). As a centralized payment system to the e-samsat supervisor team. 4). As an integrated payment system. 5). As a coordinator with other banks. 6). To accommodate the expansion of the tax payment channel. 7). As a liaison or collaborating with other parties or third parties such as Indomaret, Alfamart, Tokopedia and Bukalapak

\section{Structure}

The structure in the policy network refers to the pattern of relations between the actors involved in implementing the policy. This can be seen in the image below:

Figure 2

Network Structure of E-Samsat and PT. Bank BJB, Tbk.

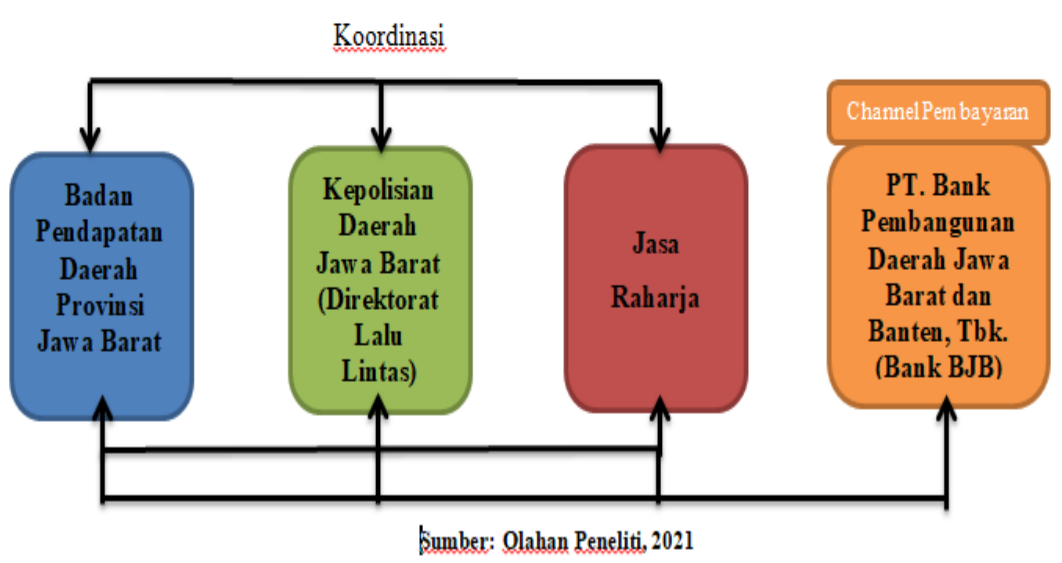

In the picture above, it can be seen that there is such a thing as the E-Samsat Development Team in the policy network structure, namely the West Java Bapenda, West Java Regional Police (Dirlantas Jabar), Jasa Raharja has a coordinating relationship in the implementation of E-Samsat. At the same time, Bank BJB is only a payment channel. And still, have a coordinating relationship with the E-Samsat coaching team. Therefore, the policy network structure is formed based on a mutual agreement so that these actors always collaborate so that the implementation of e-samsat can be carried out in accordance with the goals that have been set.

\section{Institutionalization}

The degree of institutionalization refers to the formal characteristics of the policy network and its stability. This will depend on the shape/characteristic of the structure of the 
policy network, and the higher the level of institutionalization of a policy network, the more influential the policy network will be.

The E-Samsat Development Team always conducts discussions every three months regarding implementing E-Samsat with PT. Bank BJB, Tbk. carried out in various places in order to continue to build their networks consistently, this can be seen from the picture below:

Figure 3

Forum Group Discussion E-Samsat Network

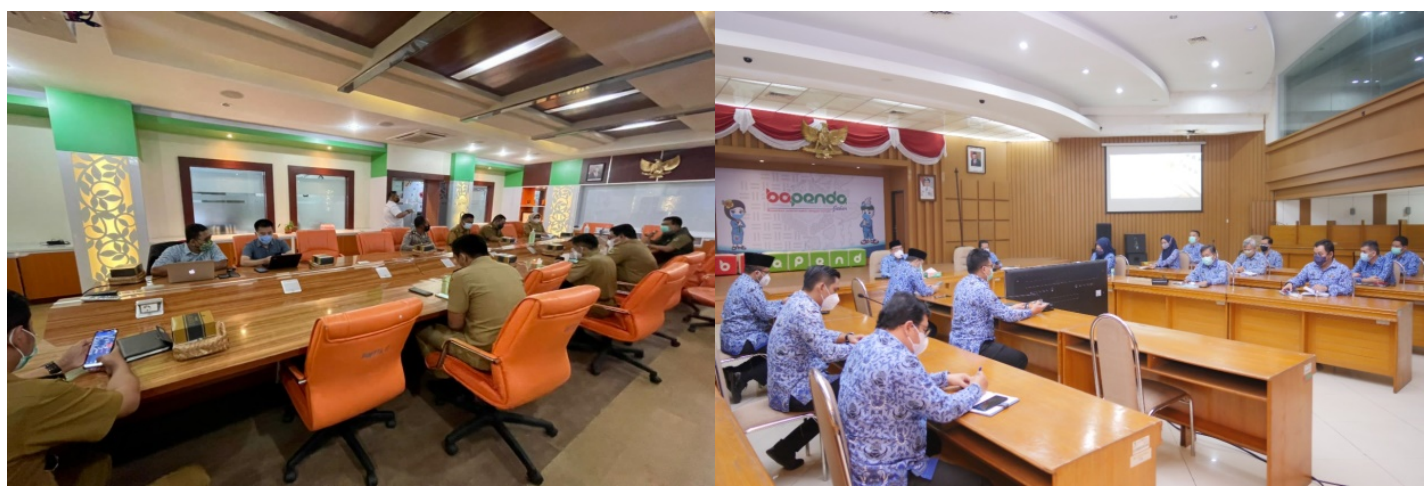

Source: Local Revenue Office of West Java, 2021

Figure 4

Discussion Session E-Samsat with Bank BJB

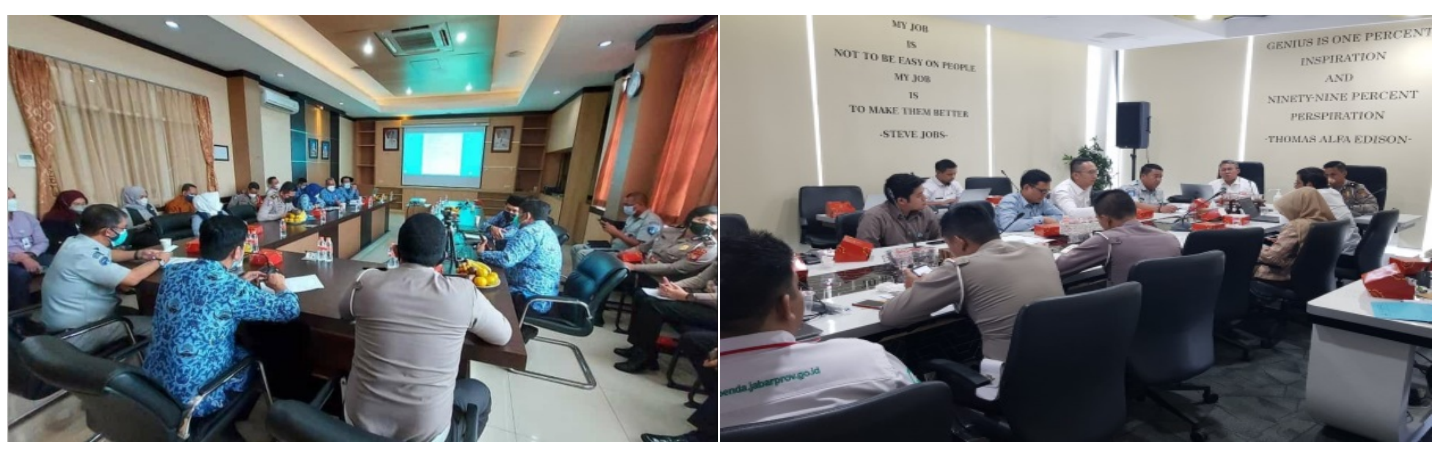

Source: Bank Jabar Banten, 2021

Figure 5

Joint Event with Stakeholders Regarding E-Samsat's Services

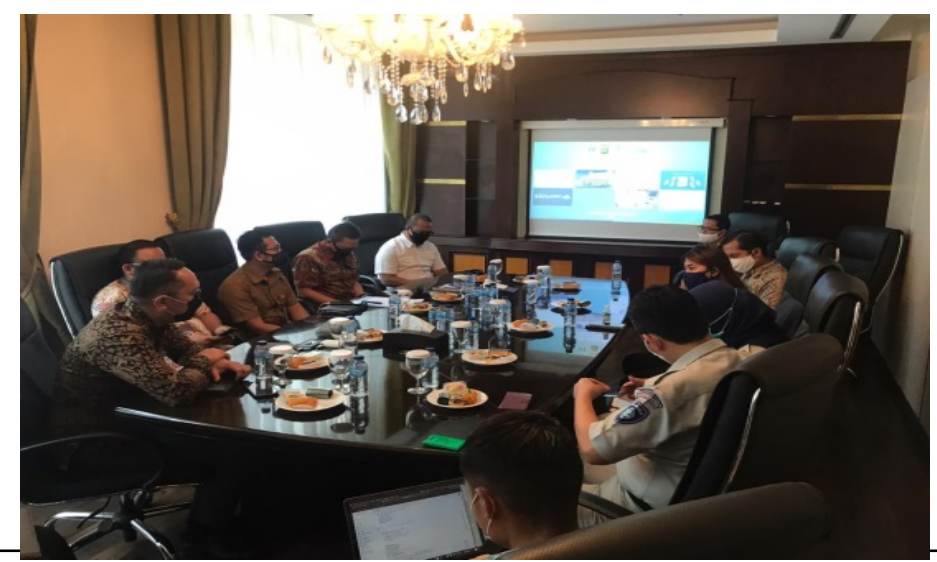

Yulia Hanoselina, Iip Permana, Krismena Tovalini, Yoserizal

Network Policy E-Samsat in Local Revenue Office of West Java Province 


\section{Rules of Conduct}

Source: Bank Jabar Banten, 2021

The game's habits or rules then form the network in the interactions that govern exchanges in a policy network. This is sourced from the perception of the role (role perception), attitudes (attitudes), interests (interest), and social and educational background (social and intellectual-educational background) of the actors involved in implementing the policy.

In the implementation of e-samsat, the West Java Province Samsat Development Team entered into a cooperation agreement carried out once every five years, which has been extended two times. The agreement contains various provisions that will be carried out, including rights, obligations, financing and profit-sharing systems. And this is a reference for implementing E-Samsat actors to act. This can be seen from the cover of the cooperation agreement of the E-Samsat Trustees team below:

Figure 6

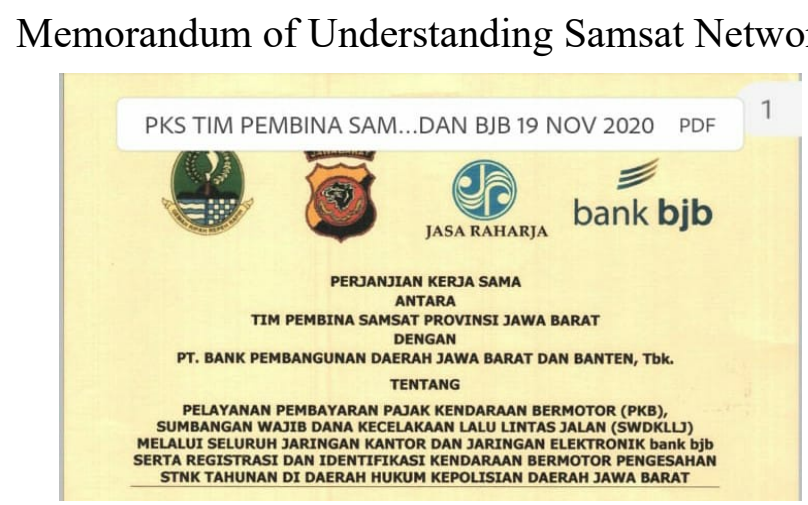

Source: Local Revenue Office of West Java, 2021

\section{Power Relations}

One of the main characteristics of the policy network is power relations which can be understood through observing the distribution of power in policy implementation. This process takes the form of a function of distributing resources and needs among policy actors and between organizational structures when an organization is involved. For example, this can be seen in the image below:

Figure 7

Hubungan Kekuasaan Tim Pembina E-Samsat dengan Bank BJB

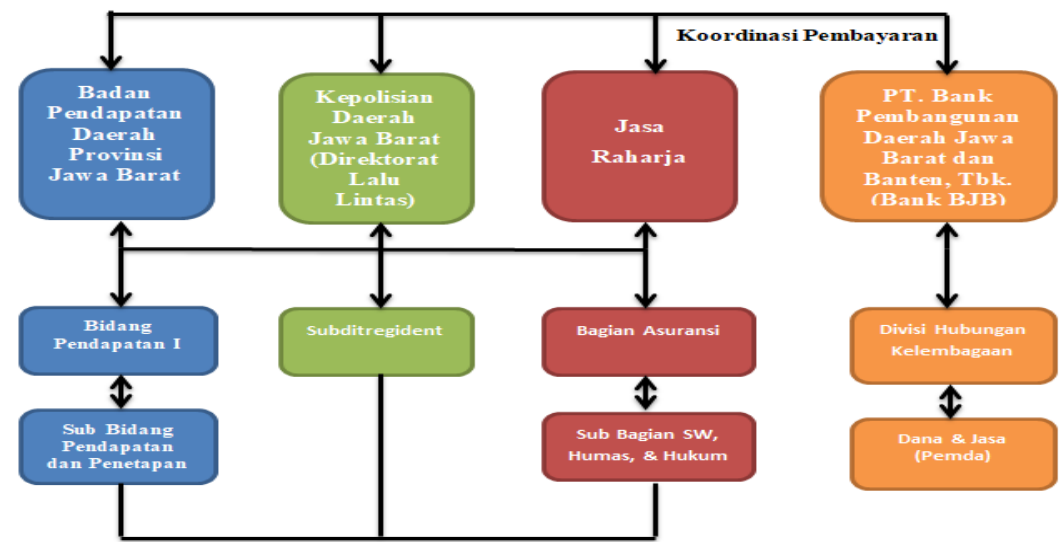

Yulia Hanoselina, Iip Permana, Krismena Tovalini, Yoserizal 
From the picture above, it can be seen that there is a power relationship from top to bottom, where each institution of the E-Samsat Guidance Team assigns their respective units to implement the implementation of E-Samsat directly. For example, from the first network, it can be seen that the West Java Bapenda assigned the Revenue Sector I and then forwarded it back to the Revenue and Determination Sub-Sector. This section has a function regulated in the Governor of West Java Province Regulation No. 80 of 2016: 1). It reviews technical policy materials in the revenue sector I, 2). Carry out the management and facilitation of income I, 3). It is conducting evaluation and reporting on Revenue Sector I and 4). Carry out other functions in accordance with the primary duties and functions.

In carrying out its main tasks, the Revenue Sector I own the following duties. First, they are assessing the work program in the Revenue Sector I. Second, they are reviewing technical policy materials in the revenue sector I. Third, they are carrying out the activities of inspecting materials for coordination, guidance and technical control in the revenue sector I. Forth, they are organizing service facilitation and objections. Fifth, they contain bookkeeping management and provide billing facilitation. Sixth, they review technical guidance materials for data collection and determination, complaints and services, bookkeeping and collection for PKB, BBNKB and PAP revenues. Seventh, they are carrying out follow-up processes for the Audit Result Report for the scope of the Revenue Sector I. Eighth, they are organizing a staff review process for consideration in making policy. Ninth, they are conducting the material assessment as a recommendation for consideration regarding the revenue sector I as material for formulating provincial government policies. Tenth, they are organizing control activities to implement the main tasks and functions of the Revenue Sector I. Eleventh, they are coordinating and developing PPPD and PLOPD. Twelveth, they are evaluating and reporting on Revenue Sector I and Performing other tasks in accordance with their primary duties and functions.

From the second network, it can be seen that the West Java Regional Police (Dirlantas) has assigned a Sub-Directorate. This section has the following tasks: to carry out the implementation and to conduct guidance on the implementation of motorized vehicle registration, driver's license, vehicle registration, and motorized vehicle owner's book (BPKB). The Sub-directorate carries out the following functions in carrying out its duties: 1). Conducting coaching on the implementation of the Resident SIM 2). Conducting training on the implementation of the Resident STNK, and 3). Guide the implementation of motorized vehicle registration and BPKB. In carrying out their duties, the Sub-Directorate is assisted by: 1). Driver's License Section (Si SIM), which fosters and administers the Resident SIM 2). Section for Motorized Vehicle Registration Numbers (STNK) promotes and helps Resident STNK and 3). Motorized Vehicle Ownership Book Section (Si BPKB) is in charge of fostering and administering motorized vehicle registration and BPKB.

From the third network, it can be seen that Jasa Raharja assigned the Insurance Section and then it was forwarded back to the Sub Division, SW, Public Relations \& Law. This section has the following main tasks: 1) Determine the validity period of the STNK/fines. 2). Quoting SWDKLJ, Fines, KD. 3). Citing IWKBU Bus \& Taxi. 4). Deposit funds are received from IW $\&$ SWDKLJ to the Bank every day. 5). Coordinate with related partners.

From the fourth network, it can be seen that PT. Bank BJB, Tbk assigned the Division of Institutional Relations and then forwarded it back to Funds \& Services (Pemda). This section 
has the following main tasks and functions: 1). Marketing of Institutional Products and Services. 2). Carry out Customer Maintenance Activities in order to increase other collaborations with the Regional Government. 3). Conducting Service Development for Regional Governments. 4). Performing the Management of Regional Government Funds

\section{Actor Strategies}

In policy networks, actors use networks as a strategy to manage their interdependence. They create and use policy networks to achieve their needs, interests, and goals. It can be seen from the image below:

Figure 8

Actor Strategy between E-Samsat Team and Bank Jabar Banten

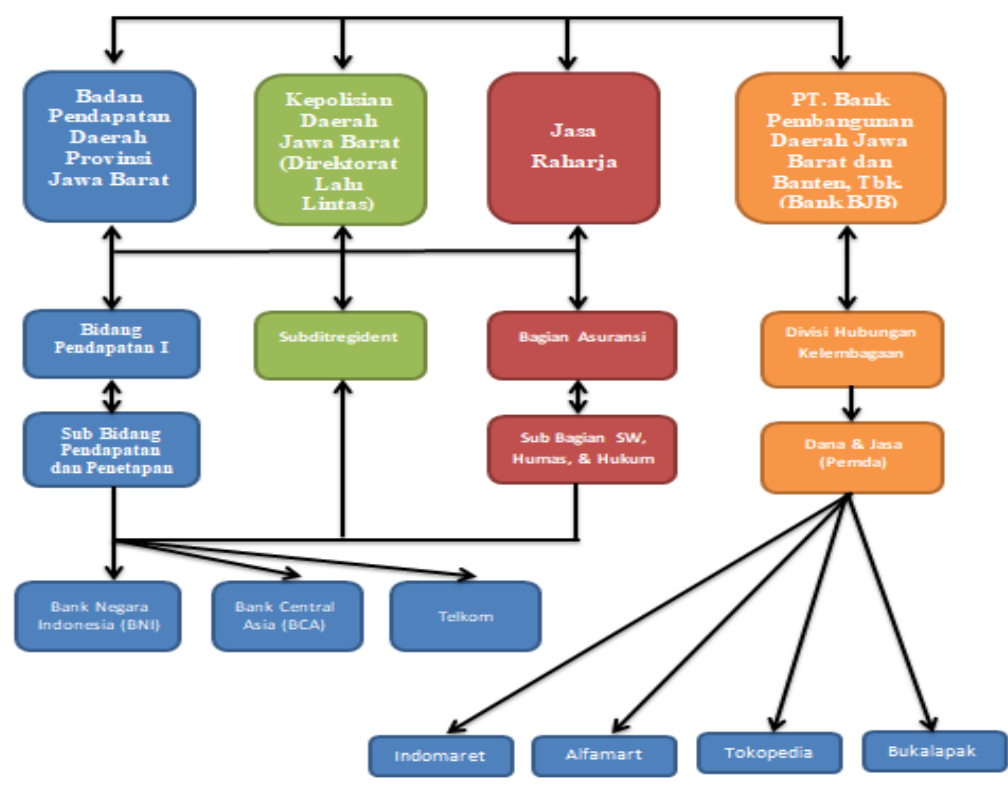

Source: Processed by Researcher, 2021

From the picture above, it can be seen that the West Java Bapenda, West Java Regional Police (Dirlantas), Jasa Raharja and PT. Bank BJB, Tbk. in improving the strategy of its actors by building cooperation and expanding its network with other parties/third parties to make it easier for the public to obtain E-Samsat services, namely with BNI Bank, BCA Bank, PT Telkom Indonesia Tbk, Indomaret, Alfamart, Tokopedia and Bukalapak. In this case, the actors who play a role in improving the actors' strategies with the public and private parties are Bapenda Jabar and PT. Bank BJB, Tbk. They always try to improve relations/networks by expanding the network by making agreements/MOUs to enjoy e-samsat services.

\section{Conclusion}

E-Samsat Implementation Policy Network at the West Java Bapenda involving several parties, namely the E-Samsat Development Team consisting of the West Java Bapenda, West Java Regional Police (Dirlantas), Jasa Raharja and in collaboration with PT. Bank BJB, Tbk and also involving other parties such as Bank BNI, Bank BCA, PT Telkom Indonesia Tbk, Alfamart, Indomaret, Bukalapak and Tokopedia 
The E-Samsat Implementation Policy Network already has its respective roles and carries out its main tasks and functions as stated in the rules of the Cooperation Agreement. The structure and pattern of power relations in the implementation of e-samsat are the same/equal between fellow e-samsat coaching teams. The E-Samsat Advisory Team is the formulator and implementer of the policy, while Bank BJB is a channel for receiving payments (payment points) for e-samsat and as a liaison or collaborating with other parties or third parties such as other banks, Indomaret, Alfamart, Tokopedia and Bukalapak. And if there are problems related to e-samsat, they are together to solve these problems according to their respective roles and produce a joint decision.

The authors' suggestions that can be given are as follows: 1). It is necessary to conduct a particular study for the West Java Bapenda to solve problems related to the internet network by adding a network with Telkom or other providers so that E-Samsat is more easily accessible. 2). Special studies need to be carried out more routinely and intensely for the E-Samsat Development Team to conduct discussions regarding the implementation of E-Samsat policies. 3). It is necessary to complete a particular study for the West Java Bapenda to expand the implementation of cooperation with other payment media parties to add a network to facilitate the payment process for the community. 4). It is necessary to conduct a study from the West Java Bapenda to regularly socialize all E-Samsat service products so that all people know and understand them. 5). It is necessary to conduct a particular study for the West Java Bependa to increase the number of human resources to support the E-Samsat service process to be more effective and efficient.

\section{References}

Bahtiar, R. (2018). Implementasi Sistem Pembayaran Pajak Kendaraan Bermotor . Bandung: Digital Library UIN Sunan Gunung Djati.

Benson, (1982). An Investigation of Motivational Bias in Subjective Predictive

Probability Distributions. A Journal of The Decision Sciences Institute. 225239

Carlsson Et Al. (2000) Network Implications in Schizophrenia. Policy Studies Journal. 502520

Dea Ayu Silvia (2019): Kualitas Pelayanan E-Samsat Di Badan Pendapatan Daerah Provinsi Jawa Barat Pada Samsat Pusat Pengelolaan Pendapatan Daerah Kota Bandung III Soekarno Hatta. Repository Universitas Pasundan

Enroth, H. (2011). Policy Network Theory. The Sage Handbook of Governance. 19-35.

Habibullah. (2010). Kajian Pemanfaatan dan Pengembangan E-Government.

Hadi, S. (2004). Metodologi Reasearch (Jilid 2). Yogyakarta: ANDI.

Hanoselina, Y., Wahyuni, N., Tovalini, K., \& Yoserizal. (2020). The Improvement of Digital Service Capacity in Immigration Office Class I TPI Padang. Atlantis Press, 158-168.

Hertiarani , W. (2016). Implementasi Kebijakan E-Samsat Di Jawa Barat. Jurnal Ilmu Administrasi, 419-440. 
Howlett, Michael dan M. Ramesh, 1995, Studying Public Policy: Policy Cycles and Policy Subsistem, Canada, Oxford University Press.

Huberman, M. B. (1992). Analisis data kualitatif: Buku sumber tentang metode-metode baru. Penerjemah : Tjetjep Rohendi Rohidi. Jakarta: Universitas Press.

Instruksi Presiden Republik Indonesia Nomor 6 Tahun 2001 Tentang Pengembangan dan Pendayagunaan Telematika di Indonesia

Instruksi Presiden Republik Indonesia Nomor 3 Tahun 2003 Tentang Kebijakan dan Strategi Nasional Pengembangan E-government

Kenis, P. N., \& Schneider, V. (1991). Policy Networks And Policy Analysis: Scrutinizing A New Analytical Toolbox. In B. Marin, \& R. Mayntz (Eds.), Policy Networks: Empirical Evidence And Theoretical Considerations. Westview Press. 25-59

Kickert, W. J. M., Klijn, E-H. and Koppenjan, J. F. M., Eds. (1997). Managing Complex Networks: Strategies for the Public Sector. London: Sage.

Moleong, L. J. (1996). Metodologi Penelitian Kualitatif. Bandung: Remaja Rosdakarya.

Nazir, M. (2003). Metode Penelitian. Jakarta: Ghalia Indonesia.

Pasolong, H. (2012). Metode Penelitian Administrasi Publik. Bandung: Alfabeta.

Rhodes (1995). The Changing Face of British Public Administration. Sage

Satori, D., \& Aan, K. (2012). Metodologi Penelitian Kualitatif. Bandung: Alfabeta.

Silvia, A. D. (2019). Kualitas Pelayanan E-Samsat Di Badan Pendapatan Daerah Provinsi Jawa Barat Pada Samsat Pusat Pengelolaan Pendapatan Daerah Kota Bandung III Soekarno Hatta. Bandung: Repository Universitas Pasundan.

Sugiyono. (2009). Metode Penelitian Kuantitatif, Kualitatif dan R\&D. Bandung: Alfabeta.

Waarden, F.V, (1992). Dimensions And Types of Policy Networks. European Journal of Political Research. 